\title{
PENGARUH MODEL PEMBELAJARAN FREE INQUIRYTERHADAP HASIL BELAJAR SISWA MATA PELAJARAN MATEMATIKA KELAS III MI BAHRUL ULUM
}

\author{
Zuni Humairoh \\ Institut Agama Islam Bani Fattah Jombang \\ zunihumairoh6@gmail.com \\ Fiki Ni'mar Rifdah \\ Institut Agama Islam Bani Fattah Jombang \\ fikinimarr@gmail.com
}

\begin{abstract}
Learning models are planning to create learning effectively and efficiently. Research focus, to know: a) How to study free inquiry in Madrasah Ibtidaiyah Bahrul Ulum Jombang class III A? b) How is the outcome of students learning MI Bahrul Ulum Jombang class III A?

The study used a simple linear regression analysis test and a classic assumption test. This research is a quantitative study of simple regression types. Its population, a total of 718 students, samples of research, using random sampling techniques using probability theory, the sample amounted to 37 students. The research instrument is a poll using a Likert scale. Instruments to collect data in the form of model free inquiry, and student learning results. Analysis of results Using Test-t (T-Test).

The results showed that, there is an independent variable influence on dependent variables, from the results of test- $t$ calculations, with the details: a) Learning free inquiry in Madrasah Ibtidaiyah Bahrul Ulum Jombang class III A very
\end{abstract}


good, with the result of $100 \%$ achievement. b) The influence of the model of free inquiry towards the outcome of learning outcomes of class III A MI Bahrul Ulum Jombang obtained the value $\mathrm{T}$ count $=6.814$ that, $\mathrm{T}$ count $>\mathrm{T}$ table IE 6.814 $>2.021$ significant standard/probability value is $0.000<$ 0.05 then Ho rejected and $\mathrm{Ha}$ accepted

Keywords: Learning outcomes and models of free Inquir

\section{PENDAHULUAN}

Pendidikan merupakan bentuk usaha dasar dan terencana untuk mewujudkan suasana belajar dan proses pembelajaran agar siswa secara aktif dapat menyesuaikan diri sebaik mungkin terhadap lingkungannya, serta dapat menimbulkan pengaruh perubahan yang baik. Siswa juga bisa mengembangkan potensi dirinya untuk memiliki kekuatan spiritual keagamaan, kepribadian, kecerdasan, serta keterampilan yang diperlukan dirinya, masyarakat dan Negara. ${ }^{1}$

Pada dasarnya proses belajar merupakan suatu proses yang menimbulkan serangkaian perbuatan guru dan siswa atas dasar hubungan timbal balik yang berlangsung untuk mencapai tujuan tertentu. Guru dan siswa merupakan syarat utama bagi berlangsungnya pembelajaran. Proses pembelajaran bisa berjalan secara optimal perlu adanya strategi pembelajaran. Strategi pembelajaran menurut Arthur L Costa seperti yang di kutip oleh Rustaman merupakan pola kegiatan pembelajaran berurutan yang diterapkan dari waktu ke waktu.Dalam komponen pembelajaran mencakup tiga hal antara lain: tujuan, model, dan evaluasi. ${ }^{2}$

Begituhalnya dengan pembelajaran matematika merupakan salah satu bidang studi yang menduduki peranan penting dalam dunia pendidikan, karena dalam pelaksanaanya matematika diberikan pada semua jenjang pendidikan, mulai dari SekolahDasar sampai perguruan tinggi. Oleh karena itu, matematika sebagai ilmu dasar yang perlu dikuasai dengan benar oleh siswa,terutama sejak usia sekolah dasar. ${ }^{3}$

Berdasarkan hasil observasi dan wawancara dengan guru mata pelajaran matematika Ibu Nanik Halimatus Sa'diyah S.sos di MI Bahrul Ulum Jombang, di peroleh jumlah siswa kelas III A sebanyak 37 siswa, guru menjelaskan bahwa selama ini proses pembelajaran dilakukan secara

\footnotetext{
1 Trianto, Model-model Pembelajaran Inovatif Berorientasi Konstruktivistik, (Jakarta: Prestasi Pustaka 2011 ) hlm 135

2 Fathurrohman Muhammad, Model-Model Pembelajaran Inovatif, (Jogjakarta: Ar-Ruzz Media, 2015) hlm. 104.

${ }^{3}$ Ibid.
} 
konvensional.Pembelajaran di kelas sering menggunakan metode ceramah, penugasan dan tanya jawab. Mengingat waktu dan target yang ada di MI Bahrul Ulum, metode ceramah dianggap paling cepat dalam menyelesaikan materi. Pada saat peneliti mengikuti proses pembelajaran siswa diberi soal matematika yang berbeda dengan contoh soal, ada beberapa siswa yang kebingungan dalam mengerjakan. Guru mengatakan bahwa ada siswa yang masih lemah dalam menghafal perkalian maupun pembagian, hal ini dikarenakan kurangnya keaktifan siswa dalam belajar.

Hal ini bisa dilihat dari penilaian tengah semester ganjil yang diperoleh siswa kelas III MI Bahrul Ulum Jombang. KKM yang sudah ditetapkan oleh sekolah pada mata pelajaran matematika yaitu70. Terdapat beberapa siswa yang nilainya masih di bawah KKM dengan presentase siswa yang tuntas sebanyak $60 \%$, sedangkan siswa yang masih belum tuntas sebanyak $40 \%$, dari 37 siswa yang tuntas sebanyak 22 siswa, sedangkan sebanyak 15 siswa yang belum tuntas, hal ini dikarenakan siswa kurang memperhatikan guru pada saat proses pembelajaran berlangsung.

Melihat hal tersebut, guru harus bisa memahami karakteristik siswa dan mencari metode yang tepat, dalam proses pembelajaran. Peneliti memilih kelas III sebagai objek penelitian karena adanya permasalahan terhadap hasil belajar siswa yang masih belum mencapai KKM. Peneliti menggunakan model pembelajaran Free Inquiry karena model pembelajaran Free Inquiry merupakan rangkaian kegiatan pembelajaran yang menekankan pada proses berfikir secara kritis dan analitis untuk mencari dan menemukan sendiri jawaban dari suatu masalah yang dipertanyakan. ${ }^{4}$ Berdasarkan latar belakang yang telah peneliti paparkan di atas, maka peneliti melakukan penelitian yang berjudul " Pengaruh Model Pembelajaran Free Inquiry terhadap Peningkatan Hasil Belajar Matematika Kelas III A MI Babrul Ulum”.

Penelitian terdahulu ini menjadi salah satu acuan dalam melakukan penelitian. Berikut merupakan penelitian terdahulu nama Laily Azizah yang berjudul: "Pengaruh Pembelajaran Matematika Model Inkuiri terhadap Kemampuan Berpikir Kreatif Siswa Kelas IV MI Miftahul Ulum Jakarta Tahun Ajaran 2013/2014”. Berdasarkan hasil penelitian tersebut, pembelajaran matematika menggunakan model pembelajaran inkuiri dan konvensional, terlihat perbedaan dalam kemampuan berpikir.Kelas yang diajarkan dengan menggunakan model inkuiri lebih tinggi dari kelas yang diajarkan dengan menggunakan pendekatan konvensional.

${ }^{4}$ Sanjaya, Wina Strategi Pembelajarn Berorientasi Standar Proses Pendidikan, (Jakarta: Kencana, 2011) hlm. 196. 
Skripsi atas nama C. Nita Rumiyati yang berjudul: "Pengaruh Model Pembelajaran Inquiry Terhadap Hasil Belajar Siswa Kelas IV MI Hayatul Islamiyah Cinangka Yogyakarta". Hasil penelitian tersebut diketahui bahwa ada hubungan yang signifikan antara model pembelajaran inquiry terhadap hasil belajar.

Berdasarkan penelitian relevan yang pernah dilakukan oleh beberapa peneliti di atas maka peneliti selanjutnya melakukan penelitian dengan dengan judul Pengaruh Model Pembelajaran Free Inquiry Terhadap Hasil Belajar Siswa Mata Pelajaran Matematika Kelas III MI Bahrul Ulum.

\section{Tempat dan Waktu Penelitian}

Penelitian ini dilakukan di MI Bahrul Ulum Jombang yang berlokasi di desa Tambak Rejo, Kecamatan Jombang, Kabupaten Jombang.

\section{Populasi dan Sampel}

Populasi yang diambil oleh penelitiyakni keseluruhan siswa MI Bahrul Ulum Tambakberas Jombang yang berjumlah sebanyak 718 siswa.Teknik pengambilan sampel menggunakan teknik random sampling mengingat penelitian bersifat homogen. Sampel yang diambil dalam penelitian ini adalah 10\% sehingga sampel yang diambil yaitu 37 siswa dari kelas III A. Penentuan jumlah sampel dalam penelitian ini mengacu dari rumus Roscoe. ${ }^{5}$

\section{Teknik Pengambilan Data}

Angket atau kuesioner dalam penelitian ini menggunakan skala likert, maka variabel yang diukur dijabarkan menjadi indikator-indikator yang dapat diukur.Indikator tersebut digunakan sebagai titik tolak untuk membuat item instrumen yang berupa pertanyaan atau pernyataan yang perlu dijawab oleh responden. Setiap jawaban dihubungkan dengan setiap bentuk pernyataan atau dukungan sikap yang digunakan dengan memberi tanda pada pilihan jawaban yang terdiri dari, sangat setuju (SS), setuju (S), kurang setuju (KS) dan tidak setuju (TS). ${ }^{6}$

Observasi terstrukturpengamatan dilakukan apabila peneliti telah tahu dengan pasti tentang variabel apa yang akan diamati. Pengamatan yang dilakukan dengan menggunakan instrumen penelitian yang sudah teruji validitas dan realibilitas dan angket tertutup juga bisa dijadikan

\footnotetext{
5 Sugiyono, Metode Penelitian Pendidikan kuantitatif, Kualitatif dan R\&D (Bandung: Alfabeta, 2016), 13

${ }^{6}$ Ibid, 135.
} 
pedoman dalam melakukan observasi.Dokumentasidigunakan untuk mendukung instrument angket dalam penelitian ini yaitu arsip data tentang sekolah MI Bahrul Ulum Jombang dan nilai harian guru.

Instrumen yang digunakan oleh peneliti dalam penelitian tersebut adalah berupa jasa kuesioner tertutup yang dimaksud kuesioner tertutup yakni sebuah instrumen pengumpulan data yang berupa sederetan pentanyaan atau informasi dalam wujud konkrit yang ditujukan kepada responden, dimana cara menjawabnya dengan memberi tanda silang atau centang sebab jawaban alternatifnya sudah ditetapkan oleh peneliti sebelumnya

\section{Model Inquiry}

Guru sebagai komponen penting dalam dunia kependidikan yang memiliki tugas untuk melaksanakan proses pembelajaran. Pada pelaksanaan pembelajaran guru diharapkan menggunakan model pembelajaran yang sesuai, salah satu model pembelajaran yang cocok untuk mata pelajaran matematikah adalah model inquiry karena menekankan pada proses pembelajaran agar siswa berpikir kritis dan analitis.

Dahar mengungkapkan kebaikan pengetahuan yang diperoleh dengan belajar inkuiri adalah: 1) pengetahuan akan bertahan lama dalam ingatan siswa danlebih mudah diingat jika dibandingkan pengetahuan yang dipelajari dengan cara-cara lain. 2) hasil belajar akan mempunyai efek transfer yang lebih baik daripada hasil belajar lainnya.

3) meningkatkan daya nalar siswa dan kemampuan berpikir bebas. ${ }^{7}$

Peran guru dalam menggunakan metode inkuiri lebih banyak menetapkan diri sebagai pembimbing atau pemimpin belajar dan fasilitator belajar. Siswa lebih banyak melakukan kegiatan sendiri atau dalam bentuk kelompok memecahkan masalah dengan bimbingan guru. Pengetahuan dan keterampilan yang diperoleh siswadiharapkan bukan hasil mengingat seperangkat fakta-fakta, tetapi hasil dari menemukan sendiri. Pengajar harus selalu merancang kegiatan yang merujuk pada kegiatan menemukan., apapun materi yang diajarkannya. ${ }^{8}$

Berdasarkan pemaparan di atas model inquiry adalah suatu proses antara guru dan siswa secara bersama-sama memecahkan masalah, dengan cara mencari dan menemukan, yang nantinya akan terdapat perbedaan pendapat dari jawaban masalahnya.

\section{Belajar dan Hasil Belajar}

${ }^{7}$ Dahar Ratna Wilia, Teori Belajar dan Pembelajaran (Bandung: Erlangga, 2011) hlm 65. ${ }^{8}$ Suwarno, et. All, Pengajaran Mikro (Yogyakarta: Tiara Wacana, 2006) hlm 81 
Proses belajar memegang peranan yang sangat penting dalam proses pengajaran. Belajar merupakan kegiatan yang terjadi pada semua orang tanpa mengenal batas usia. Kegiatan belajar dapat terjadi dimanapun. Seseorang dianggap telah belajar sesuatu jika dia dapat menunjukkan perubahan tingkah lakunya.

Bertolak dari perubahan yang ditimbulkan oleh perbuatan belajar, para ahli teori belajar berusaha merumuskan pengertian belajar.Belajar juga dimaknai sebagai interaksi individu dengan lingkungannya. Lingkungan dalam hal ini adalah obyek-obyek lain yang memungkinkan individu memperoleh pengalaman-pengalaman atau pengetahuan, baik pengalaman atau pengetahuan baru maupun sesuatu yang pernah diperoleh atau ditemukan sebelumnya tetapi menimbulkan perhatian kembali bagi individu tersebut sehingga memungkinkan terjadinya interaksi. $^{9}$

Hasil belajar merupakan kemampuan-kemampuan yang dimiliki siswa setelah ia menerima pengalaman belajarnya, karenahasil belajar bagian terpenting dalam pembelajaran dan hasil belajar sebagai salah satu indikator tujuan dalam belajar.

Untuk realisasi atau pemekaran dari kecakapan-kecakapan potensial atau kapasitas yang dimiliki seseorang,

\section{Hasil Penelitian Model Free Inquiry}

Hasil deskripsi variabel Model Free Inquiry (X) diterangkan bahwa terdapat 37 responden dengan rata-rata (mean) sebesar 44,27 simpangan baku (standard deviasi) sebesar 4.676 rentang (range) sebesar 24 skor minimum dalam data Model Free Inquiry adalah sebesar 27 dan skor maksimum dari data Model Free Inquiry adalah sebesar 50. Berdasarkan hasil interpretasi skor variabel Model Free Inquiry termasuk dalam kategori kuat/tinggi. Hal ini berarti Model Free Inquiry berpotensi baik dalam mendukung hasil belajar siswa.

\section{Hasil Belajar}

Hasil deskripsi variabel Hasil Belajar (Y) diterangkan bahwa terdapat 37 responden dengan rata-rata (mean) sebesar 52,32 simpangan baku (standard deviasi) sebesar 6.425 rentang (range) sebesar 27, skor minimum dalam data Hasil Belajar adalah sebesar 34 dan skor maksimum dari data Hasil Belajar adalah sebesar 60. Berdasarkan hasil interpretasi skor variabel Hasil Belajar termasuk dalam kategori kuat/tinggi. Hal ini berarti Hasil Belajar berpotensi baik dalam mendukung hasil belajar siswa.

${ }^{9}$ Ainurrahman, Belajar dan Pembelajaran (Bandung: Alfabeta, 2013) hlm 36. 


\section{Analisis}

Teknik analisa data dalam penelitian kuantitatif menggunakan data statistik. Data statistik yang digunakan dalam penelitian ini adalah statistik deskriptif, statistik deskriptif yaitu statistik yang digunakan untuk menganalisa data dengan cara menggambarkan

Data yang telah terkumpul sebagaimana adanya tanpa bermaksud membuat kesimpulan yang berlaku untuk umum atau generalisasi, yaitu teknik yang digunakan untuk memberikan pengetahuan yang signifikan dalam menggambarkan sebuah fenomena melalui proses kuantifikasi.

Teknik analisa data dalam penghitungan ini menggunakan model regresi linier sederhana yaitu: Data yang diperoleh dalam kaitannya dengan penelitian ini adalah:(1). Data tentang pengaruh model pembelajaran Free Inquiry, (2) Data tentang hasil belajar siswa, (3) Data tentang hasil belajar siswa setelah diberikannya pembelajaran matematika dengan model pembelajaran Free Inquiry. Teknik analisa data dalam penghitungannya menggunakan model regresi linier sederhana seperti di bawah ini:

\section{Teknik Analisa Regresi Linier Sederhana}

Teknik ini digunakan peneliti untuk menganalisa dua variabel yang dimaksud dalam dua rumusan masalah yaitu untuk mengetahui ada atau tidak ada pengaruh model pembelajaran Free Inquiri terhadap hasil belajar siswa. Adapun persamaan estimasi regresi linier sederhana dengan rumus sebagai berikut:

$$
\mathrm{Y}=\mathrm{a}+\mathrm{bX}
$$

\section{Keterangan:}

$\mathrm{Y}=$ Variabel response atau variabel akibat (Dependent)

$\mathrm{X}=$ Variabel predictor atau variabel factor penyebab (Independent)

$\mathrm{a}=$ Konstanta

$\mathrm{b}=$ Koefisien regresi (kemiringan), besaran response yang ditimbulkan oleh predictor

\section{Uji Asumsi Klasik}

Uji asumsi klasik diperlukan untuk mengetahui apakah hasil estimasi regresi yang dilakukan benar-benar bebas dari adanya gejala normalitas, gejala multikolinearitas, dan gejala autokorelasi. Beberapa uji asumsi klasik yang akan dipaparkan sebagai berikut:

\section{Normalitas}


Uji asumsi ini menguji data variabel bebas $(\mathrm{X})$ dan data variabel terikat $(\mathrm{Y})$ pada persamaan regresi yang dihasilkan apakah berdistribusi normal atau tidak. ${ }^{10}$

Teknik ini dilakukan untuk memudahkan peneliti dalam hal perhitungan dan analisis data yang diperoleh dari lapangan. Dasar pengambilan keputusan teknik ini yaitu:

a. Jika data menyebar disekitar garis diagonal dan mengikuti arah garis diagonal, maka model regresi memenuhi asumsi normalitas.

b. Jika data menyebar jauh dari garis diagonal dan tidak mengikuti arah garis diagonal, maka model regresi tidak memenuhi asumsi normalitas.

\section{Multikolinearitas}

Penyimpangan multikolinearitas ${ }^{11}$ adalah hubungan antar variabel independent yang terdapat dalam model mempunyai hubungan yang sempurna atau mendekati sempurna. Model regresi yang baik seharusnya tidak terjadi multikolinearitas.Konsekuensinya pada teknik ini jika terjadi multikolinearitas maka koefisien korelasi tidak tertentu dan tingkat kesalahan menjadi sangat besar. Secara matematis pengukuran multikolinearitas dirumuskan sebagai berikut:

VIF bis $=11-$ Ri2

Keterangan:

$\mathrm{R} 2$ = koefisien determinasi

Keterangan di atas berhubungan dengan persamaan variabel inflasi jika mempunyai nilai yang semakin besar menunjukkan multikolinearitas akan lebih sederhana. Apabila nilai faktor varian inflasi lebih dari 10, maka terjadi multikolinearitas.

\section{Gejala Autokorelasi}

Autokorelasi ${ }^{12}$ dapat diartikan sebagai korelasi antar anggota observasi atau antar sesama yang disusun sesuai waktu dan tempat.Model regresi yang baik, seharusnya tidak terjadi autokorelasi. Pendeteksian adanya otokorelasi dalam situasi tertentu memakai uji Durbin Watson. Uji otokorelasi dengan menggunakan uji Durbin Watson ${ }^{13}$ adalah sebagai berikut:

a. Ho $: \varrho=0$

\footnotetext{
${ }^{10}$ Rochmat Aldy Purnomo, Analisis Statistik Ekonomi dan Bisnis Dengan SPSS, (Purwosari: Cv. Wade Group, 2016), 108

${ }^{11}$ Ibid, 116.

${ }^{12} \mathrm{Ibid}, 123$.

${ }^{13}$ Dyah Nirmala Arum Janis Statistik Deskriptif \& Regresi Linier Berganda Dengan SPSS. (Semarang: Semarang University Press, 2012.) hlm 30.
} 
H1 $: \varrho \neq 0$

b. Nilai DW (Durbin Watson) menggunakan rumus:

$\mathrm{d}=t=2 t=\mathrm{Ne} 1-\mathrm{et}-12 t=1 \mathrm{t}=\mathrm{Net} 2$

c. Nilai statistik hitung di atas dibandingkan dengan nilai teoritis di bawah ini:

1. Otokorelasi positif $(>0)$

a) Jika DW $>$ du maka $\mathrm{H} 0$ diterima

b) Jika $\mathrm{Dw}<\mathrm{dL}$ maka $\mathrm{H} 0$ ditolak

c) Jika dL $<$ DW $<$ du, maka tidak dapat diambil kesimpulan dan disarankan untuk memperbesar sampel.

2. Otokorelasi negatif $(<0)$

a) Jika $(4-\mathrm{DW})=\mathrm{du}$, maka H0 diterima

b) Jika (4-DW) $=\mathrm{dL}$, maka H0 ditolak

\section{Uji Heteroskedastisitas}

Uji heteroskedastisitas ${ }^{14}$ ini digunakan untuk menguji antara observasi satu dengan yang lain apakah residualnya mempunyai varians yang sama atau tidak. Persamaan regresi yang baik yaitu jika tidak terjadi heteroskedastisitas dan tidak terajadi heteroskedastisitas jika pada scatterplot titik-titiknya mempunyai pola yang teratur, melebar atau menyebar maupun bergelombang (berarti terjadi homoskedastisitas).Namun sebaliknya, jika terjadi heterokedastisitas jika mempunyai pola menyempit, bergelombang dan tidak teratur.

\section{Pembahasan}

Variabel Model Free Inquiry memberikan pengaruh yang signifikan dan positif terhadap Hasil Belajar Siswa materi pecahan pada pembelajaran Matematika siswa kelas III MI Bahrul Ulum Jombang.Hal ini ditunjukkan dengan hasil koefisien korelasi sebesar 0,334 lebih besar daripada nilai signifikansi sebesar 0,05 atau $5 \%$.

\begin{tabular}{|c|c|c|c|c|c|c|}
\hline $\begin{array}{c}\text { Variabel } \\
\text { Depen } \\
\text { Dent }\end{array}$ & $\begin{array}{l}\text { No } \\
\text { indika } \\
\text { tor }\end{array}$ & $\begin{array}{c}\text { Scale } \\
\text { Mean if } \\
\text { Item } \\
\text { Deleted }\end{array}$ & $\begin{array}{c}\text { Scale } \\
\text { Variance } \\
\text { if Item } \\
\text { Deleted }\end{array}$ & $\begin{array}{c}\text { r } \\
\text { hitu } \\
\text { ng }\end{array}$ & $\begin{array}{c}\mathbf{r} \\
\text { tabel }\end{array}$ & $\begin{array}{c}\text { Inter } \\
\text { Pre } \\
\text { tasi }\end{array}$ \\
\hline \multirow{5}{*}{$\begin{array}{l}\text { Reliabel } \\
\text { Pembelaj } \\
\text { aran } \\
\text { inkuiri } \\
(\mathrm{X})\end{array}$} & $\mathrm{X}$ & 39.78 & 19.396 & .523 & 0,334 & Valid \\
\hline & $\mathrm{X}$ & 40.08 & 17.362 & .613 & 0,334 & Valid \\
\hline & $X$ & 40.19 & 19.547 & .353 & 0,334 & Valid \\
\hline & $\mathrm{X}$ & 39.89 & 17.932 & .669 & 0,334 & Valid \\
\hline & $\mathrm{X}$ & 40.16 & 16.917 & .461 & 0,334 & Valid \\
\hline
\end{tabular}

${ }^{14}$ Sugiyono.Statistik \& Penelitian, (Bandung: Alfabeta, 2006) hlm. 79 


\begin{tabular}{|c|c|c|c|c|c|c|}
\hline & $\mathrm{X}$ & 40.00 & 17.444 & .572 & 0,334 & Valid \\
\cline { 2 - 7 } & $\mathrm{X}$ & 40.35 & 17.512 & .496 & 0,334 & Valid \\
\cline { 2 - 7 } & $\mathrm{X}$ & 40.30 & 18.381 & .401 & 0,334 & Valid \\
\cline { 2 - 7 } & $\mathrm{X}$ & 40.08 & 17.362 & .613 & 0,334 & Valid \\
\hline
\end{tabular}

Sumber SPSS. V.20

Tabel tersebut menunjukkan bahwa semua item pernyataan kuesioner untuk model pembelajaran Free Inquiry (Variabel X) dinyatakan valid. Hal ini dibuktikan dengan hasil dari nilai korelasi (r) lebih besar dari $r$ tabel.

\begin{tabular}{|l|c|c|c|c|c|c|}
\hline $\begin{array}{c}\text { Variabel } \\
\text { Depend } \\
\text { ent }\end{array}$ & $\begin{array}{c}\text { No } \\
\text { indika } \\
\text { tor }\end{array}$ & $\begin{array}{c}\text { Scale } \\
\text { Mean if } \\
\text { Item } \\
\text { Deleted }\end{array}$ & $\begin{array}{c}\text { Scale } \\
\text { Varian } \\
\text { ce if } \\
\text { Item } \\
\text { Deleted }\end{array}$ & $\begin{array}{c}\mathbf{r} \text { hitu } \\
\text { ng }\end{array}$ & $\begin{array}{c}\mathbf{r} \\
\text { tabel }\end{array}$ & $\begin{array}{c}\text { Interpr } \\
\text { etasi }\end{array}$ \\
\hline \multirow{4}{*}{$\begin{array}{l}\text { Hasil } \\
\text { Belajar }\end{array}$} & $\mathrm{Y}$ & 47.86 & 36.676 & .366 & 0,334 & Valid \\
\cline { 2 - 7 } & $\mathrm{Y}$ & 48.00 & 35.667 & .437 & 0,334 & Valid \\
\cline { 2 - 7 } & $\mathrm{Y}$ & 48.16 & 34.029 & .433 & 0,334 & Valid \\
\cline { 2 - 7 } & $\mathrm{Y}$ & 47.59 & 36.581 & .542 & 0,334 & Valid \\
\cline { 2 - 7 } & $\mathrm{Y}$ & 47.89 & 33.710 & .677 & 0,334 & Valid \\
\cline { 2 - 7 } & $\mathrm{Y}$ & 47.68 & 37.947 & .346 & 0,334 & Valid \\
\cline { 2 - 7 } & $\mathrm{Y}$ & 47.92 & 37.299 & .390 & 0,334 & Valid \\
\cline { 2 - 7 } & $\mathrm{Y}$ & 47.86 & 36.231 & .432 & 0,334 & Valid \\
\cline { 2 - 7 } & $\mathrm{Y}$ & 48.16 & 34.140 & .451 & 0,334 & Valid \\
\cline { 2 - 7 } & $\mathrm{Y}$ & 48.22 & 31.674 & .607 & 0,334 & Valid \\
\cline { 2 - 7 } & $\mathrm{Y}$ & 48.35 & 33.790 & .415 & 0,334 & Valid \\
\cline { 2 - 7 } & $\mathrm{Y}$ & 47.86 & 35.842 & .450 & 0,334 & Valid \\
\hline
\end{tabular}

Sumber SPSS. V.20

Tabel tersebut menunjukkan bahwa semua item pernyataan kuesioner untuk hasil belajar siswa (variabel Y) dinyatakan valid. Hal ini dibuktikan dengan hasil dari nilai korelasi (r) lebih besar daripada r tabel.

\begin{tabular}{|c|c|c|}
\hline Variabel Independent & $\begin{array}{c}\text { Cronbach's } \\
\text { Alpha }\end{array}$ & Interpretasi \\
\hline $\begin{array}{c}\text { Model Pembelajaran Free } \\
\text { Inquiry }\end{array}$ & 0,7871 & Reliable \\
\hline
\end{tabular}

Sumber SPSS. V.20

Pada Tabel tersebut menunjukkan bahwa nilai hitung Cronbach Alpha (a) $>0,6$ yaitu sebesar 0,7871 maka dapat diketahui bahwa untuk variabel X (model pembelajaran free inquiry) dinyatakan reliabel. 


\begin{tabular}{|c|c|c|}
\hline $\begin{array}{c}\text { Variabel } \\
\text { Independent }\end{array}$ & Cronbach's Alpha & Interpretasi \\
\hline Hasil Belajar & 0,79183 & Reliable \\
\hline
\end{tabular}

Sumber SPSS. V.20

Pada Tabel tersebut menunjukkan bahwa nilai hitung Cronbach Alpha (a) $>0,6$ yaitu sebesar 0,79183, maka dapat dijelaskan bahwa untuk variabel Y (hasil belajar siswa) dinyatakan reliabel.

\begin{tabular}{|l|c|c|}
\hline \multirow{2}{*}{ Model } & \multicolumn{2}{|c|}{ Colinearity Statistics } \\
\cline { 2 - 3 } & Tolerance & VIF \\
\hline (Constant) & .1000 & .1000 \\
X1 & & \\
& & \\
\hline
\end{tabular}

Sumber SPSS. V.20

Berdasarkan hasil tabel di atas menunjukkan bahwa besar a hitung $>$ a standar $(1,000$ atau $100 \%>10 \%)$ dan VIF hitung $<$ VIF $(1,000<$ 10) dan semua tolerance variabel bebas $=(1,000=100 \%)$. Pada tabel diatas dapat diketahui bahwa antar variabel bebas tidak terjadi multikolinieritas.

Persamaan regresi yang baik adalah tidak memiliki masalah autokorelasi. Apabila terjadiautokorelasi maka persamaan tersebut menjadi tidak layak untuk dijadikan prediksi.Salah satu ukuran dalam menentukan ada tidaknya masalah autokorelasi yaitu dengan menggunakan uji Durbin-Waston (DW) seperti ktentuan sebagai berikut:

a) Terjadi autokorelasi positif jika nilai DW dibawah $-2(\mathrm{DW}<-2)$

b) Tidak terjadi autokorelasi jika nilai DW berada di antara -2 dan $+2(-$ $2<\mathrm{DW}<+2$ )

c) Terjadi autokorelasi negatif jika nilai DW di atas $+2(\mathrm{DW}>+2)$

\begin{tabular}{|c|c|c|c|c|c|}
\hline Model & $\mathbf{R}$ & R Square & $\begin{array}{c}\text { Adjusted R } \\
\text { Square }\end{array}$ & $\begin{array}{c}\text { Std. } \\
\text { Error of } \\
\text { the } \\
\text { Estimate }\end{array}$ & $\begin{array}{c}\text { Durbin } \\
\text { Watson }\end{array}$ \\
\hline 1 & $.555^{\mathrm{a}}$ & .370 & .358 & 2.272 & 1.134 \\
\hline
\end{tabular}

Sumber SPSS. V.20 


\begin{tabular}{|l|r|r|r|r|l|}
\hline Residual Statisticsa & \multicolumn{1}{|c|}{$\begin{array}{c}\text { Mini } \\
\text { mum }\end{array}$} & $\begin{array}{c}\text { Maxi } \\
\text { mum }\end{array}$ & Mean & $\begin{array}{r}\text { Std. } \\
\text { Deviatio } \\
\mathbf{n}\end{array}$ & $\mathbf{~ N ~}$ \\
\hline Predicted Value & & & & & \\
Std. Predicted Value & 34.41 & 58.27 & 52.32 & 4.851 & 37 \\
Standard Error of & -3.693 & 1.225 & .000 & 1.000 & 37 \\
Predicted Value & .704 & 2.722 & .935 & .339 & 37 \\
Adjusted Predicted & 31.95 & 58.66 & 52.27 & 5.099 & 37 \\
Value & -14.932 & 7.956 & .000 & 4.212 & 37 \\
Residual & -3.495 & 1.862 & .000 & .986 & 37 \\
Std. Residual & -3.568 & 1.888 & .005 & 1.013 & 37 \\
Stud. Residual & -15.564 & 8.178 & .054 & 4.460 & 37 \\
Deleted Residual & -4.409 & 1.964 & -.018 & 1.106 & 37 \\
Stud. Deleted & .003 & 13.638 & .973 & 2.218 & 37 \\
Residual & .000 & .406 & .031 & .077 & 37 \\
Mahal. Distance & .000 & .379 & .027 & .062 & 37 \\
Cook's Distance & & & & & \\
Centered Leverage & & & & & \\
Value & & & & & \\
\hline
\end{tabular}

Berdasarkan hasil dari tabel bahwa nilai Durbin-Waston $=1,134$ dan DW hitung terletak di antara -2 dan $+2(-2<$ DW $<+2)$. Hal ini dapat dikatakan bahwa tidak terjadi autokorelasi, karena $-2<1,134<+2$. Sumber SPSS. V.20

Berdasarkan tabel diatas dapat diketahui bahwa nilai residual tersebut mempunyai varians yang sama, cenderung lebih seragam dan tidak bervariasi karena selisihnya kecil. Variabel bebas pada tabel di atas mengalami homoskedastistas dan tidak terjadi heteroksedastistas.

\section{Hasil Uji Heteroskedastisitas pada Scatterplot}

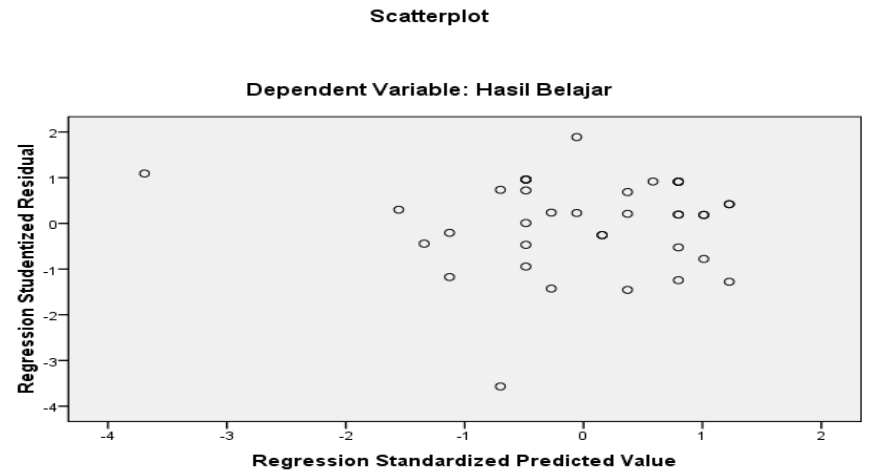


Berdasarkan gambar di atas menunjukkan bahwa, pada scatterplot terdapat titik-titik hasil dari pengolahan data antar ZPRED dan SRESID terlihat menyebar di bawah, di atas, maupun menyimpang dan tidak mempunyai pola yang teratur. Hal ini dapat dikatakan bahwa variabel bebas tersebut tidak terjadi heteroskedastitas akan tetapi terjadi homoskedastistas.

\section{Hasil Uji Normalitas pada Grafik Histogram}

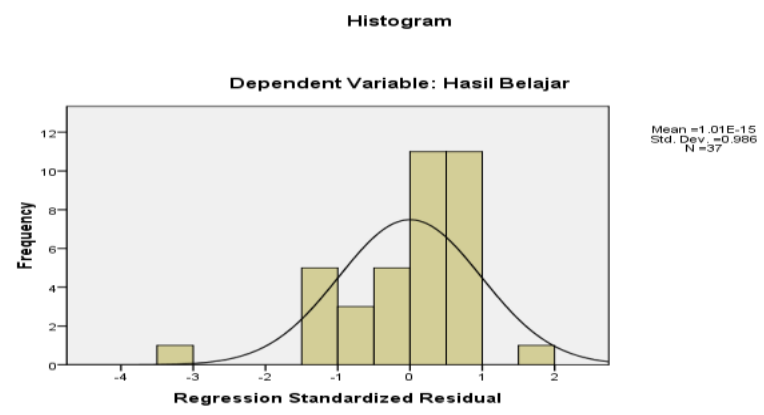

\section{Uji Normalitas pada Scatterplots}

Berdasarkan hasil dari kedua gambar di atas dapat diketahui bahwa hasil grafik histogram berada pada garis kurva yang normal. Demikian juga dari normal probability plots, menunjukkan beridstribusi normal karena garis (titik-titik) mengikuti garis diagonal.

\section{Hasil Pengujian Hipotesis secara Parsial}

\begin{tabular}{|c|c|c|c|c|c|}
\hline \multirow[t]{2}{*}{ Model } & \multicolumn{2}{|c|}{$\begin{array}{l}\text { Unstandardized } \\
\text { Coefficient }\end{array}$} & $\begin{array}{l}\text { Standardized } \\
\text { Coefficient }\end{array}$ & \multirow[t]{2}{*}{$\mathbf{T}$} & \multirow[t]{2}{*}{ Sig. } \\
\hline & B & $\begin{array}{l}\text { Std. } \\
\text { Error }\end{array}$ & Beta & & \\
\hline 1 (Constant) & 6.398 & 6.777 & & .944 & .352 \\
\hline X (Model & 1.037 & .152 & .755 & 6.81 & .000 \\
\hline Inquiry) & & & & 4 & \\
\hline
\end{tabular}

Sumber SPSS. V.20

Berdasarkan tabel di atas didapatkan analisis regresi sederhana yang digunakan untuk mengetahui pengaruh model pembelajaram Free Inquiry terhadap hasil belajar siswa. Hasil dari penghitungan SPSS V.20 diperoleh persamaan regresi sederhana sebagai berikut:

$\mathrm{Y}=\mathrm{a}+\mathrm{bX}$

$\mathrm{Y}=6398+1037 \mathrm{X}$ 


\section{Kesimpulan}

Berdasarkan rumusan masalah dan hasil penelitian yang telah dipaparkan maka dapat disimpulkan bahwa, terdapat pengaruh positif yang signifikan antara Model free Inquirydengan Hasil Belajar koefisien korelasisebesar 0,334 lebih besar daripada nilai signifikansi sebesar 0,05 atau 5\%.Hasil dari output uji parsial $(\mathrm{t})$ diperoleh nilai $\mathrm{T}$ hitung $=6,814$ menunjukkan bahwa T hitung $>\mathrm{T}$ tabel yaitu 6,814 $>2,021$ dan standar signifikansi/nilai probabilitas (a) 0,000 $<0,05$ maka Ho ditolak dan Ha diterima. Hal ini menunjukkan bahwa, nilai koefisien regresi prediktor model pembelajaran Free Inquiry signifikan dan terdapat pengaruh terhadap hasil belajar siswa.

\section{DAFTAR PUSTAKA}

Ainurrahman, Belajar dan Pembelajaran (Bandung: Alfabeta, 2013)

Dahar Ratna Wilia, Teori Belajar dan Pembelajaran (Bandung:Erlangga, 2011)

Dyah Nirmala Arum Janie Statistik Deskriptif \& Regresi Linier Berganda Dengan SPSS. (Semarang: Semarang University Press, 2012.).

Fathurrohman, Muhammad, Model-Model Pembelajaran Inovatif, Jogjakarta: Ar-Ruzz Media, 2015).

Rochmat Aldy Purnomo, Analisis Statistik Ekonomi dan Bisnis Dengan SPSS, (Purwosari: C Wade Group, 2016).

Sanjaya, Wina, Strategi Pembelajarn Berorientasi Standar Proses Pendidikan, (Jakarta: Kencana, 2011).

Sugiyono, Metode Penelitian Pendidikan kuantitatif, Kualitatif dan $R \& D$ (Bandung: Alfabeta, 2016). , Metode Penelitian Pendidikan. (Bandung: Alfabeta, 2016). , Statistik \& Penelitian, (Bandung: Alfabeta 2002).

Suwarno, et. All, Pengajaran Mikro (Yogyakarta: Tiara Wacana, 2006) Trianto, Model-model Pembelajaran Inovatif Berorientasi Konstruktivistik, (Jakarta: Prestasi Pustaka 2011 ). 